\title{
Seismic Performance of a High-Rise Building by Using Linear and Non-Linear Methods
}

Özlem Çavdar ( $\square$ ozlem_cavdar@hotmail.com )

Gümüşhane University

\section{Research Article}

Keywords: High-Rise Building, Irregular Building, Seismic performance evaluation, Linear and non-linear seismic evaluation methods, Risk Assessment.

Posted Date: August 4th, 2021

DOI: https://doi.org/10.21203/rs.3.rs-688918/v1

License: (c) (i) This work is licensed under a Creative Commons Attribution 4.0 International License. Read Full License 
1

21

\title{
Seismic Performance of a High-Rise Building by Using Linear and Non-Linear Methods Özlem Çavdar" ${ }^{* 1}$ \\ ${ }^{1}$ Gümüşhane University, Department of Civil Engineering 29000, Gümüşhane, Turkey.
}

\begin{abstract}
In this paper, the seismic behavior of existing reinforced concrete tall building is investigated by the linear and nonlinear dynamic analysis. The selected reinforced concrete structure was designed according to "Turkey Seismic Code-2007" (TEC-2007). A typical 41 story reinforced concrete building is designed. Turkey Building Earthquake Code-2018 (TBEC-2018) is utilized for evaluating the seismic performance of the selected building. Natural earthquake acceleration record selected and adjusted for compatibility with the adopted design spectrum, is used.

A performance analysis according to the TBEC-2018 in a 41-story reinforced concrete shear wallframed structure in Istanbul where active fault lines are located. The selected reinforced concrete shear wall unsymmetrical plan tall building is located in Istanbul, Turkey. The performance goals of the reinforced concrete shear wall structure are evaluated by applying procedures of the TBEC-2018 and nonlinear dynamic analysis. According to the Code, the reinforced concrete shear wall building is not expected to satisfy life safety performance levels under design earthquake.
\end{abstract}

Keywords: High-Rise Building, Irregular Building, Seismic performance evaluation, Linear and nonlinear seismic evaluation methods, Risk Assessment.

\section{Introduction}

Seismic behavior and principles of earthquake. resistant structural design included structural engineering codes of various countries take important part in the code of Turkey. After destructive earthquakes, determination of seismic of existing structures gained great importance. In addition, a large number of existing reinforced concrete shear wall unsymmetrical plan tall buildings in first-degree seismic zone need seismic evaluation because of their unfavorable seismic behavior, types of irregularities in plan and in elevation.

Especially serious damages and many losses happened after 1989 Loma Prieta and 1994 Northridge earthquakes in the United States of America, 1995 Kobe earthquake in Japan; 1992 Erzincan, 1999 Marmara and Duzce and 2011 Van earthquakes in Turkey. Therefore, performance-based design procedures have been investigated for the irregular recently. Performance-based design and evaluation methods have been developed in order to determine building safety more realistically than previous codes or just reastically and contribute to strengthening structures that are considered to have insufficient safety. Few codes in the world have regulatory requirements towards performance based seismic design of tall buildings. Seismic Design Code for Tall Buildings in Istanbul. was proposed in 2008; however, it not been implemented yet. After the devastating earthquake in Turkey occurred in 2007, the buildings were heavily damaged. For this reason, Turkey Building Earthquake Code (TBEC-2018) was published in 2018 and special rules for the design of high building carrier systems under earthquake effect 
have been added. There are several procedures for performance assessment in the literature. The most common assessment procedures are explained in four main guidelines/codes which are Federal Emergency Management Agency (FEMA-440), Applied Technology Council (ATC-40), FEMA 356, and Turkish Building Earthquake Code (TBEC-2018). TBEC-2018 came into use in 2019. As the tendency to build high buildings in Turkey increases, the 2018 Turkey Building Earthquake Regulation has added special rules section for the design of high building stone systems under the influence of earthquakes. Tall buildings; are under the influence of repetitive loads that change over time. Starting from the design phase, the most important feature of a high structure during the projected service life is that it is not the only feature that a high structure should have; to maintain its structural integrity without a noticeable decrease in its strength due to external loads. The concept of performance-based design and evaluation is the most important of the developments observed in earthquake and structural engineering. This design approach has been developed as an alternative to the traditional strength-oriented design approach. The nonlinear seismic performances of structures under earthquake effects are determined by static pushover and time history analyses. Pushover analysis allows for direct evaluation of the performance of the structure at each limit state (Duan and Hueste, 2013, Tehranizadeh and Moshref, 2011, Vasiliadis, 2016, Pavel and Vacareanu, 2016, Ahmad, 2021). Nonlinear dynamic analysis is the most reliable analysis method among all nonlinear analysis methodologies.

Many papers have been published on the topic of performance evaluation of existing RC buildings. Ye et al. (2008) noted the absence of the preferred strong-column, weak-beam damage mechanism in typical RC frames that were damaged in the Wenchuan earthquake. Most building structures in China are normally low- to medium-rise RC frames. Poursh et al. (2014) aimed to extend the consecutive modal pushover (CMP) procedure for estimating the seismic demands of two-way unsymmetrical-plan tall buildings subjected to bi-directional seismic ground motions taking the effects of higher modes and torsion into account. The CMP procedure features a higher potential in estimating plastic hinge rotations at both flexible and stiff sides of unsymmetrical-plan tall buildings under bi-directional seismic excitation when compared to the uniform and fundamental effective mode force distributions. Fredrick et al. (2017) seismic vulnerability assessment of soft story irregular buildings using pushover analysis. Armini and Poursh (2016) are studied the effect of higher modes in estimating the seismic demands. of tall buildings, a nonadaptive displacement-based pushover (NADP) procedure based on structural dynamics theory. Guan et al. (2019) investigated a combination model for conventional pushover analysis with invariant lateral load patterns to consider the effects of higher mode vibrations on the seismic responses of high-rise buildings. The results demonstrate that the proposed method can estimate the seismic responses of high-rise buildings with a high accuracy and has the advantages of ease of implementation and operation.

The aim of the present study is that the implementation of nonlinear dynamic analysis in order to estimate the seismic performance of an irregular in plan tall building. The building is a typical beam-column RC frame building with shear walls. The selected building was designed according to TEC-2007 considering both gravity and seismic loads. The nonlinear dynamic analysis is performed by using the finite element program Structural Analysis Program (SAP 2000). Beam and column elements are modeled as nonlinear frame elements with lumped plasticity by defining plastic hinges at both ends of beams and columns. Shear wall areas are modelled as nonlinear frame elements with distributed plasticity hinge. SAP2000 provides default or user defined hinge 
properties options to model nonlinear behavior of components. In this study, user-defined hinge properties are implemented. Seismic performance evaluation is carried out in accordance with the recently published TBEC-2018 that has similarities with FEMA-356 guidelines.

This investigated designed reinforced concrete tall building in this study is located in the city of İstanbul, Turkey. This city is under danger of approaching and inevitable Great Istanbul Earthquake likely greater than $\mathrm{Mw}$ 7. Thus, investigation of earthquake performances of this or similar tall buildings are very important.

\section{Performance Levels}

TBEC-2018, defined as the new Turkish Building Seismic Code, proposes a three-stage process, which is explained further and is based on PEER Performance Based Design approach. The tall buildings are defined Class 1 of Buildings that have heights presented in TBEC-2018.

As shown in Fig. 1a, five points labeled A, B, C, D, and E define force-deformation behavior of a plastic hinge. The values assigned to each of these points vary depending on element typed, material properties, longitudinal and transverse steel content, and axial load level on the element (ATC-40; FEMA-273; Inel et al., 2016).

Similar to ATC and FEMA, three limit conditions have been defined for ductile elements on the cross section in TBEC-2018. These are Limited Damage Performance Level (SH), Controlled Damage Performance Level (KH) and Collapse Prevention Performance Level (GÖ) (Fig. 1b). Limited Damage Performance Level (SH); the building corresponds to the level of damage to the structural system elements, whereby a limited degree of damage or non-linear behavior occurs. Controlled Damage Performance level $(\mathrm{KH})$; in order to ensure life safety, the building seismic resisting system corresponds to the level of controlled damage which is not very heavy. Collapse Prevention Performance Level (GÖ); the building corresponds to the pre-cash situation where severe damage to the structural system elements occurs. Partial or complete collapse of the building is prevented.

The definition of user-defined hinge properties requires moment-curvature analysis of each element. Mander model (Mander et all., 1988) for unconfined and confined concrete and typical steel stress-strain model with strain hardening for steel are implemented in moment-curvature analyses. The points B and C in Fig. 1-a are related to yield and ultimate curvatures. The point B is obtained from SAP2000 using approximate component initial effective stiffness values as per TBEC- 2018; 0.35EI for beams and 0.70EI for columns.

In this study, moment-curvature analyses are carried out considering section properties and a constant axial load on the structural element.

After the appropriate material properties are determined, structural element sections are modeled via XTRACT program. In the section, two concrete models, confined and unconfined concretes, are used. The modeling is concluded by inputting reinforcement steels into the defined section geometry. Thus, moment-curvature relations are determined after analyses. 


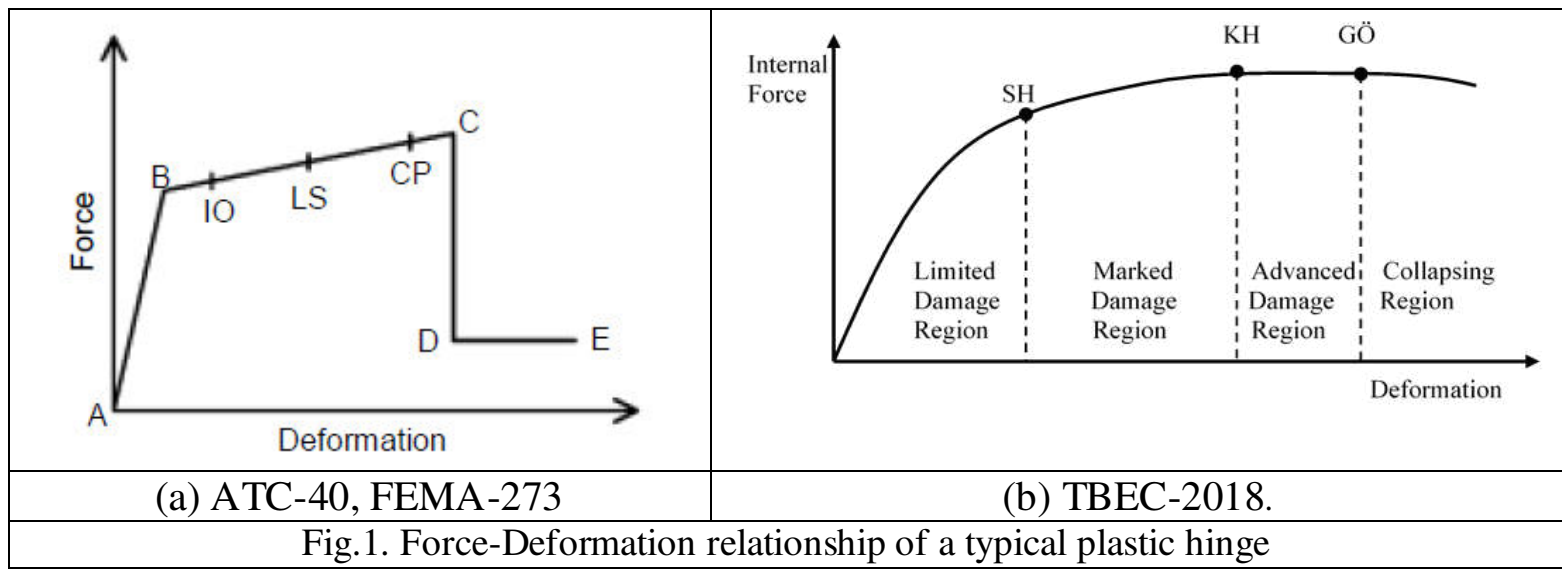

135

Plastic hinge length is used to obtain ultimate rotation values from the ultimate curvatures. The

plastic hinge length definition given in Eq. (1) is used:

$$
\mathrm{L}_{\mathrm{p}}=0.5 \mathrm{H}
$$

In Eq. (1), $L_{p}$ is the plastic hinge length, $H$ is the height of section, respectively.

Plastic rotation limit values are calculated with Equation 2 for migrant prevention performance target.

$\theta_{p}^{(G 0 ̈)}=\frac{2}{3}\left[\left(\emptyset_{u}-\emptyset_{y}\right) L_{p}\left(1-0.5 \frac{L_{P}}{L_{s}}\right)+4.5 \emptyset_{u} d_{b}\right]$

In Eq. (2), $\emptyset_{u}$ corresponds to the total pre-collapse curvature obtained from the analysis made by using the concrete-reinforcing steel models given by considering the axial force acting on the section. $\emptyset_{y}$ is yield curvature $\left(\mathrm{m}^{-1}\right), L \mathrm{~s}$ is shear opening $(\mathrm{m})$. The last term in the given $\mathrm{d}_{\mathrm{b}}$ corresponds to the return of reinforcement stripping due to yield penetration for the post-yield condition.

\section{Description of Investigated Reinforced Concrete Structure}

\subsection{Numerical Model}

The selected building is an asymmetrical tall building with shear walls. The total height of the building from the foundation level is $164 \mathrm{~m}$ with $4 \mathrm{~m}$ story height. Three-dimensional finite element model of the irregular tall building was prepared in SAP2000 structural analysis program shown in Fig. 2. The existing reinforced concrete framed building is located in Bostanc1 district of İstanbul. Due to the fact all the structural drawings and specifications are available, the reinforcedconcrete properties of structural members are assumed to be known completely. There are 50 axes in X-direction and 29 axes in Y-direction in the structural floor plan. The building consists of concrete slabs sitting on beams supported by shear walls and columns for vertical load bearing system. The vertical loads consist of live and dead loads of slabs, wall loads on beams and dead 
loads of columns and beams. The lateral load resisting system of the building consists of shear walls with coupling beams distributed in the floor plan as required by architectural needs. The projected concrete class is C50 (according to EN 206-1 standard) and projected reinforcing steel class is S420 (according to EN 10080 standard). The sizes of the spiral columns consist of $80 \mathrm{~cm}$ and $60 \mathrm{~cm}$, the dimensions of the beams the building's twenty-eight story were found to be $50 \mathrm{~cm} /$ $70 \mathrm{~cm}$ whereas the dimensions of the beams in the core region and other stories consist of $40 \mathrm{~cm} / 60$ $\mathrm{cm}$. Slab thicknesses are $20 \mathrm{~cm}$. Thicknesses of the shear walls are $40 \mathrm{~cm}$ at all stories.

A design ground acceleration of $0.4 \mathrm{~g}$ and soil class $\mathrm{ZB}$ considered. in the analyses. The dead load is $\mathrm{G}=2.04 \mathrm{kN} / \mathrm{m}^{2}$ for all the floors except the top floor where the dead load was considered as $\mathrm{G}=$ $8.5 \mathrm{kN} / \mathrm{m}^{2}$. The live load is $\mathrm{Q}=5 \mathrm{kN} / \mathrm{m}^{2}$ for each floor except the top floor. The structure is thought to be an office and its live load contribution factor is taken as $\mathrm{n}=0.3$.

The asymmetrical irregular tall building was analyzed in detail by performing nonlinear dynamic analyses according to the TBEC-2018.

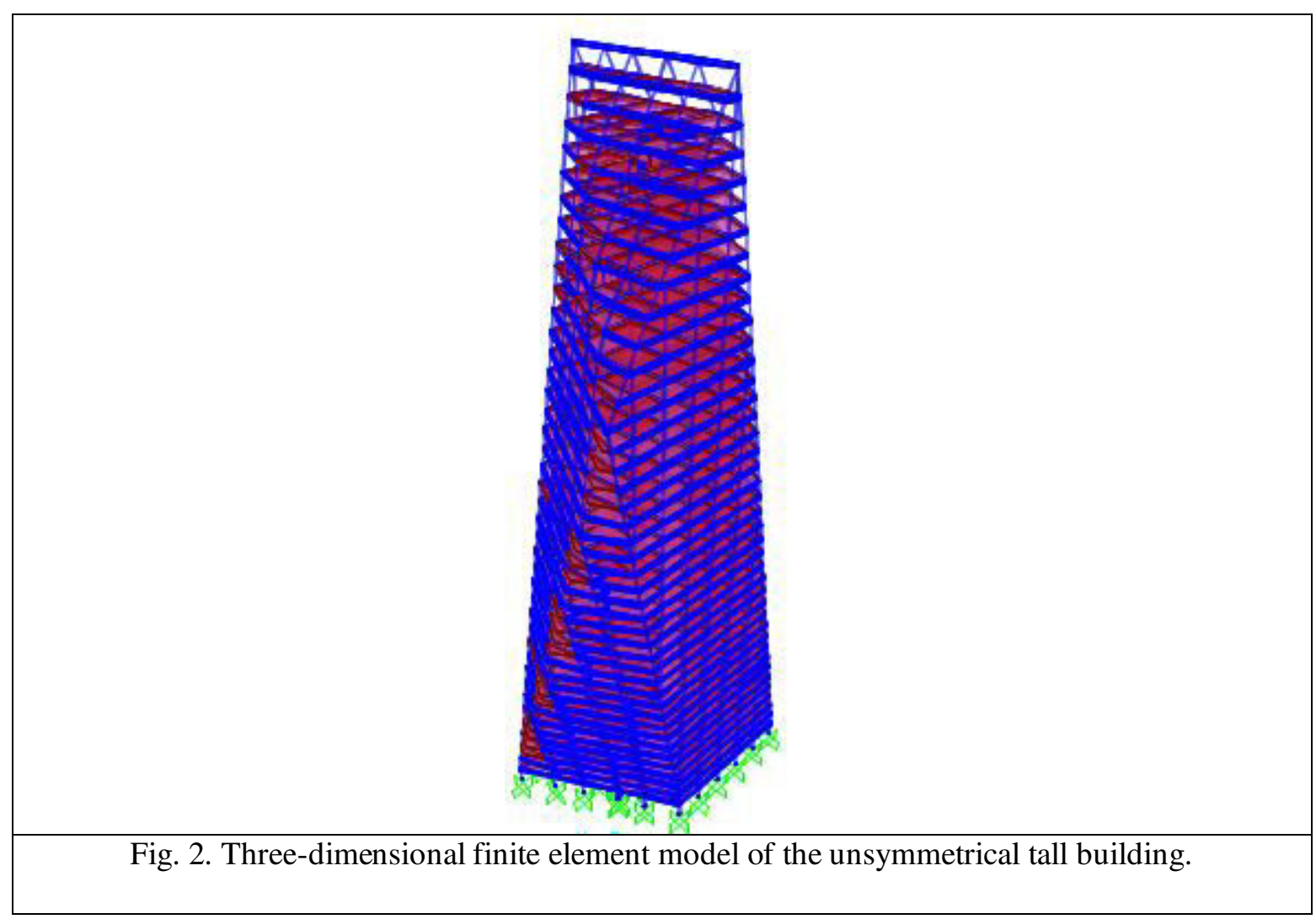

Longitudinal rebars are $25 \varnothing 28$ for $80 \mathrm{~cm}$ diameter circular columns and $22 \varnothing 28$ for $60 \mathrm{~cm}$ diameter 
and beams. Flexural rigidity is calculated for each member. Beams and columns were modeled as frame elements which were connected to each other at the joints.

The vertical loads consist of live and dead loads of slabs, wall loads on beams and dead loads of columns and beams. When determining seismic performance of the selected structure, Seismic Load Reduction Factor is taken as $R_{a}=1$. In addition, building importance factor is applied as $I=1$. The rigidities of cracked sections are taken instead of the rigidities of uncracked sections. The information level coefficient is taken as 1 for extended information level. Predominant mode periods of the building in $\mathrm{X}$ and $\mathrm{Y}$ directions are $5.836 \mathrm{~s}$ and $5.117 \mathrm{~s}$, respectively, based on cracked section properties. The first three mode shapes are given in Fig. 3. The first and second mode shapes have components in the two horizontal directions, and the third has a torsional component.

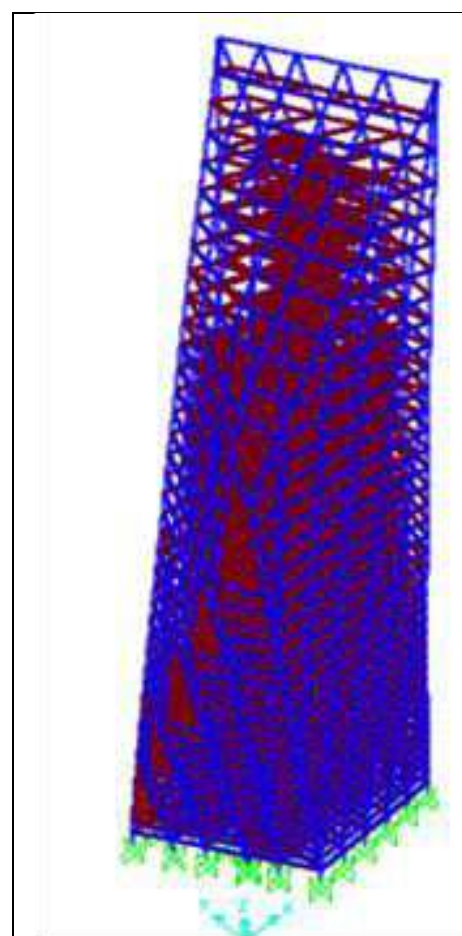

(a) First mode

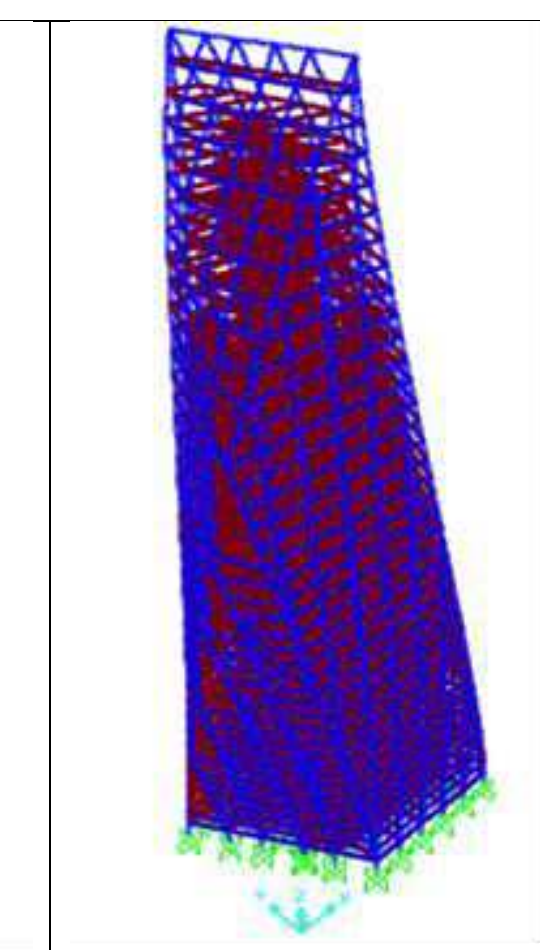

(b) Second mode

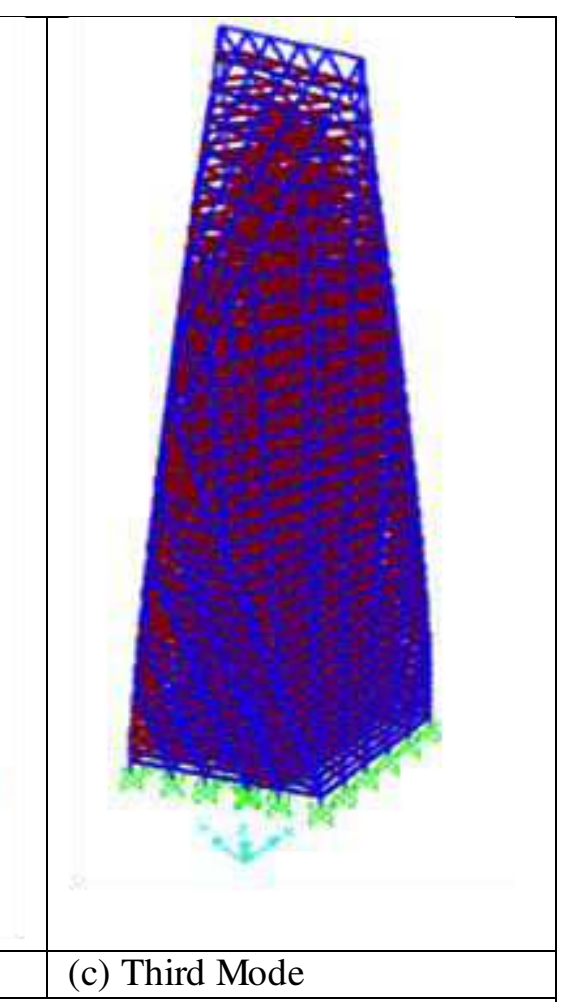

(c) Third Mode

Fig. 3. First three mode shapes of the building

The XTRACT program is utilized during the preparation of material properties, obtainment of moment-curvature relations of each structural elements and definition of axial load-moment (PM) interaction diagrams for the columns. Effective cross-section rigidity calculation of remaining parts between plastic hinges in the columns and beams is made according to TBEC-2018. The effective cross-sectional rigidities of the columns, beams and connecting beams to be modeled according to the lumped plasticity behavior are determined according to Eq. (3) Moment- curve diagrams for beams and columns are given in Fig. 4. 
In Eq. (3), My and Өy show the averages of the effective yielding moments and yielding rotations of the plastic hinges at the ends of the frame element. $L_{S}$ is the spanning shearing. The yielding rotation of the plastic hinge $(\Theta y)$ will be calculated by Eq.(4).

$$
\theta_{y}=\frac{L_{S} \emptyset_{y}}{3}+0.0015 \eta\left(1+1.5 \frac{h}{L_{s}}\right)+\frac{f_{y e} d_{b} \emptyset_{y}}{\sqrt[8]{f_{c e}}}
$$

In Eq. (4), Øy demonstrates the effective yielding curvature in the plastic hinge section, while $\mathrm{h}$ is the cross-section height. In the continuation of the formula, $\eta=1$ in beams and columns, $\eta=0.5$ in shear walls will be taken. db shows the average diameter of the reinforcement steels, while the fye and fce show the average yield resistance of the reinforcement with the average pressure resistance of the concrete.

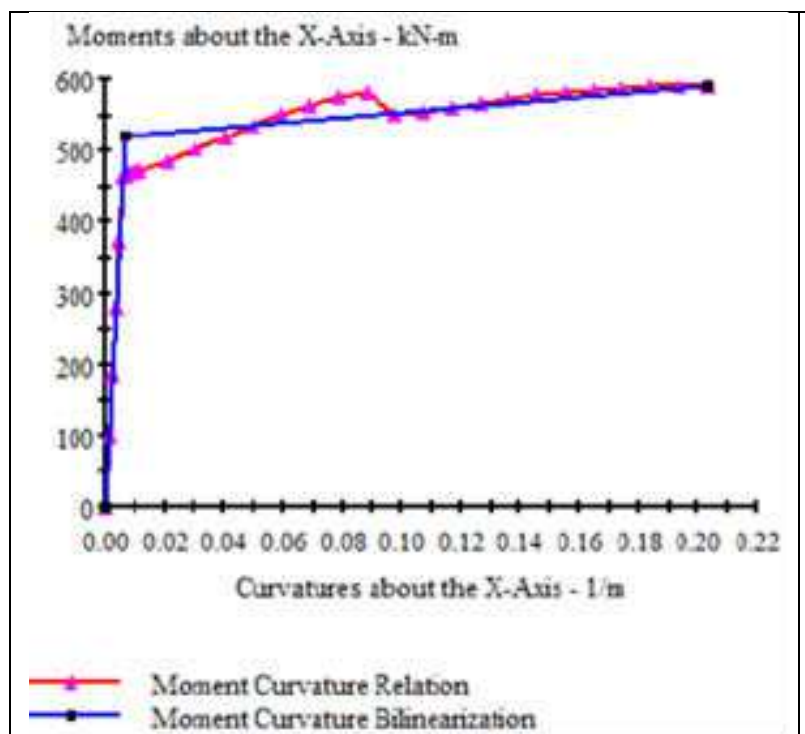

(a) Moment-curve for beams

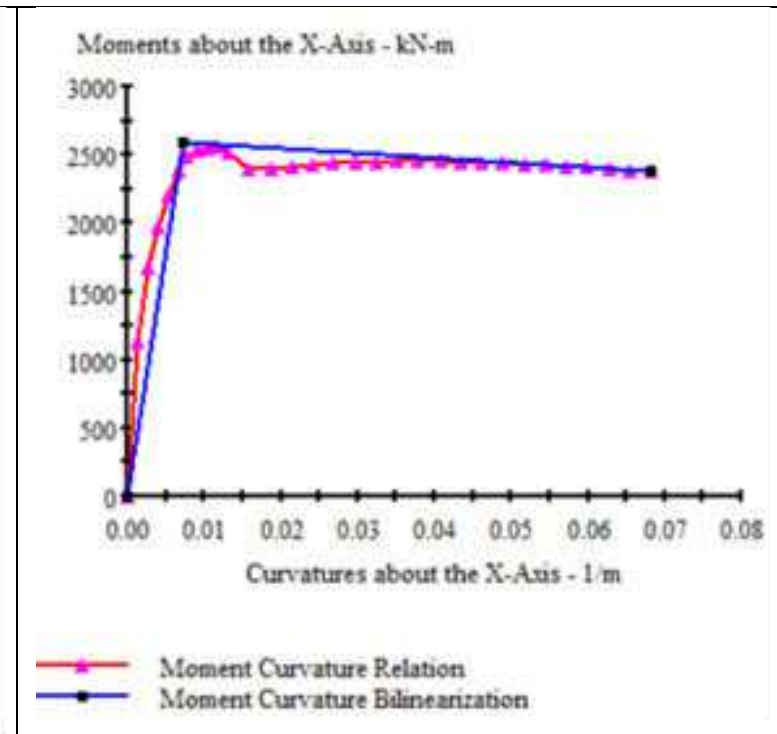

(b) Moment-curve for columns

Fig. 4. Typical moment- curve diagrams

\section{Nonlinear Seismic Performance. Evaluation of the Building}

Regarding the definition of irregular buildings whose design and construction should be avoided because of their unfavorable seismic behavior, types of irregularities in plan and in elevation. Irregularity calculations were done by applying the procedures defined in the TBEC2018 for this building. The case where Torsional Irregularity Factor $\left(\mathrm{\eta}_{\mathrm{bi}}\right)$, which is defined for any of the two orthogonal earthquake directions as the ratio of the maximum relative story drift at any story to the average relative story drift at the same story in the same direction, is greater than 1.4. 
Since the building examined is 41 storeys, the torsional irregularity coefficient has been calculated for all floors, but the results are given only for the first ten floors in the Tables 1-2. The torsional irregularity coefficient $\left(\eta_{b i}\right)$ that is calculated in accordance with the elastic linear behavior without considering additional eccentricity should meet the condition $\eta_{b i}<1.4$ for each floor.

It is seen from Table 1 and Table 2 that the torsional irregularity of the building is not provided. The interstorey stiffness irregularity ratios for first ten story given in Tables 3-4.

There are no local slab abrupt reductions in the plane. stiffness and strength of floors and seismic loads are safely. transferred to vertical structural elements. Therefore, floor discontinuities irregularity (A2) does not exist. Since the re-entrant corners in both of the two principal directions in plan do not exist, there is A3 type irregularity in the structure.

Since the height of the structure is greater than $25 \mathrm{~m}$ and there is interstorey stiffness irregularity ( be applied for the seismic analysis of the structure. Moreover, in accordance with the earthquake taken into consideration, the ratio of the active mass of the primary (dominant) vibration mode calculated. taking the linear elastic behavior as a basis point to the total mass of the building (except for the masses of the basement floors covered by the rigid frames) should be above 0.95 (TBEC, 2018). Because, the building not provides all these conditions, the time history analysis is utilized.

Vertical Load Combination (TBEC 2018)

$\mathrm{G}+\mathrm{nQ}=\mathrm{G}+0.3 \mathrm{Q}$

Table 1. The control of torsional irregularity coefficient for $\mathrm{X}$ direction of tall building

\begin{tabular}{|c|c|c|c|c|c|c|}
\hline Story & $\begin{array}{c}\text { Story } \\
\text { height } \\
(\mathrm{hi}) \\
(\mathrm{m})\end{array}$ & $\begin{array}{c}\text { Displacement } \\
(\Delta \mathrm{imax})(\mathrm{m})\end{array}$ & $\begin{array}{c}\text { Min. } \\
\text { Displacement } \\
(\Delta \mathrm{imin})(\mathrm{m})\end{array}$ & $\Delta \mathrm{i}$-ort & $\mathrm{nbi<1,4}$ & $\begin{array}{c}\text { Restriction } \\
\text { of TBEC- } \\
2018\end{array}$ \\
\hline 10 & 4 & 0.0070 & 0.0011 & 0.00405 & 1.7284 & 1.4 \\
\hline 9 & 4 & 0.0070 & 0.0019 & 0.00445 & 1.5730 & 1.4 \\
\hline 8 & 4 & 0.0068 & 0.0025 & 0.00465 & 1.4624 & 1.4 \\
\hline 7 & 4 & 0.0059 & 0.0026 & 0.00425 & 1.3882 & 1.4 \\
\hline 6 & 4 & 0.0056 & 0.003 & 0.0043 & 1.3023 & 1.4 \\
\hline 5 & 4 & 0.0056 & 0.0036 & 0.0046 & 1.2174 & 1.4 \\
\hline 4 & 4 & 0.0054 & 0.0039 & 0.00465 & 1.1613 & 1.4 \\
\hline 3 & 4 & 0.0048 & 0.004 & 0.0044 & 1.0909 & 1.4 \\
\hline 2 & 4 & 0.0037 & 0.0035 & 0.0036 & 1.0278 & 1.4 \\
\hline 1 & 4 & 0.0011 & 0.001 & 0.00105 & 1.0476 & 1.4 \\
\hline
\end{tabular}

Table 2. The control of torsional irregularity coefficient for $\mathrm{Y}$ direction of tall building.

\begin{tabular}{|c|c|c|c|c|c|c|}
\hline Story & $\begin{array}{c}\text { Story } \\
\text { height }\end{array}$ & $\begin{array}{c}\text { Displacement } \\
(\Delta \text { imax })(m)\end{array}$ & $\begin{array}{c}\text { Min. } \\
\text { Displacement }\end{array}$ & $\Delta \mathrm{i}$-ort & nbi $<1,4$ & $\begin{array}{c}\text { Restriction } \\
\text { of TBEC- }\end{array}$ \\
\hline
\end{tabular}


255

256

257

258

259

260

261

262

263

264

\begin{tabular}{|c|c|l|l|l|l|l|}
\hline & $\begin{array}{c}(\mathrm{hi}) \\
(\mathrm{m})\end{array}$ & & $(\Delta \mathrm{imin})(\mathrm{m})$ & & & 2018 \\
\hline 10 & 4 & 0.0143 & 0.0015 & 0.0079 & 1.8101 & 1.4 \\
\hline 9 & 4 & 0.0098 & 0.0017 & 0.0058 & 1.7043 & 1.4 \\
\hline 8 & 4 & 0.0075 & 0.0006 & 0.0041 & 1.8519 & 1.4 \\
\hline 7 & 4 & 0.0081 & 0.0003 & 0.0042 & 1.9286 & 1.4 \\
\hline 6 & 4 & 0.0083 & 0.0003 & 0.0043 & 1.9302 & 1.4 \\
\hline 5 & 4 & 0.011 & 0.0012 & 0.0061 & 1.8033 & 1.4 \\
\hline 4 & 4 & 0.0129 & 0.0019 & 0.0074 & 1.7433 & 1.4 \\
\hline 3 & 4 & 0.0112 & 0.0014 & 0.0063 & 1.7778 & 1.4 \\
\hline 2 & 4 & 0.0105 & 0.0013 & 0.0059 & 1.7797 & 1.4 \\
\hline 1 & 4 & 0.0092 & 0.0009 & 0.0051 & 1.8219 & 1.4 \\
\hline
\end{tabular}

In Eq. (5), $\mathrm{G}$ is total dead load, $\mathrm{n}$ is the live load participation factor, $\mathrm{Q}$ is total live load stories of building, respectively.

Table 3. The control of interstorey stiffness irregularity coefficient for $\mathrm{X}$ direction of tall building

\begin{tabular}{|c|c|l|l|l|l|l|}
\hline Story & $\begin{array}{c}\text { Story } \\
\text { height } \\
(\mathrm{hi}) \\
(\mathrm{m})\end{array}$ & $\begin{array}{c}\text { Displacement } \\
(\mathrm{di})(\mathrm{m})\end{array}$ & $\begin{array}{c}\text { Relative } \\
\text { displacement } \\
(\Delta \mathrm{i})(\mathrm{m})\end{array}$ & $(\Delta \mathrm{i} / \mathrm{hi})$ ort. & nki<1,4 & $\begin{array}{c}\text { Restriction } \\
\text { of TBEC- } \\
2018\end{array}$ \\
\hline 10 & 4 & 0.0443 & 0.0051 & 0.0013 & 0.9528 & 2.0 \\
\hline 9 & 4 & 0.0392 & 0.0053 & 0.0013 & 0.9888 & 2.0 \\
\hline 8 & 4 & 0.0339 & 0.0054 & 0.0013 & 1.1167 & 2.0 \\
\hline 7 & 4 & 0.0286 & 0.0048 & 0.0012 & 1.0127 & 2.0 \\
\hline 6 & 4 & 0.0238 & 0.0048 & 0.0012 & 0.9675 & 2.0 \\
\hline 5 & 4 & 0.0190 & 0.0049 & 0.0012 & 1 & 2.0 \\
\hline 4 & 4 & 0.0141 & 0.0049 & 0.0012 & 1.0864 & 2.0 \\
\hline 3 & 4 & 0.0093 & 0.0045 & 0.0011 & 1.2289 & 2.0 \\
\hline 2 & 4 & 0.0047 & 0.0037 & 0.0009 & 3.4952 & 2.0 \\
\hline 1 & 4 & 0.0011 & 0.0011 & 0.0003 & & 2.0 \\
\hline
\end{tabular}

Table 4. The control of interstorey stiffness irregularity coefficient for Y direction of tall building

\begin{tabular}{|c|c|c|c|c|c|c|}
\hline Story & $\begin{array}{c}\text { Story } \\
\text { height }\end{array}$ & $\begin{array}{c}\text { Displacement } \\
(\mathrm{di})(\mathrm{m})\end{array}$ & $\begin{array}{c}\text { Relative } \\
\text { displacement }\end{array}$ & $(\Delta \mathrm{i} / \mathrm{hi})$ ort. & nki<1,4 & $\begin{array}{c}\text { Restriction } \\
\text { of TBEC- }\end{array}$ \\
\hline
\end{tabular}




\begin{tabular}{|c|c|l|l|l|l|l|}
\hline & $\begin{array}{c}(\mathrm{hi}) \\
(\mathrm{m})\end{array}$ & & \multicolumn{1}{|c|}{$(\Delta \mathrm{i})(\mathrm{m})$} & & & 2018 \\
\hline 10 & 4 & 0.0617 & 0.0081 & 0.0020 & 0.9988 & 2.0 \\
\hline 9 & 4 & 0.0536 & 0.0081 & 0.0020 & 1.0278 & 2.0 \\
\hline 8 & 4 & 0.0455 & 0.0079 & 0.0019 & 1.1567 & 2.0 \\
\hline 7 & 4 & 0.0376 & 0.0068 & 0.0017 & 1.0396 & 2.0 \\
\hline 6 & 4 & 0.0308 & 0.0066 & 0.0016 & 1.0155 & 2.0 \\
\hline 5 & 4 & 0.0242 & 0.0065 & 0.0016 & 1.0254 & 2.0 \\
\hline 4 & 4 & 0.0177 & 0.0063 & 0.0016 & 1.1070 & 2.0 \\
\hline 3 & 4 & 0.0114 & 0.0057 & 0.0014 & 1.2473 & 2.0 \\
\hline 2 & 4 & 0.0057 & 0.0046 & 0.0012 & 3.9739 & 2.0 \\
\hline 1 & 4 & 0.0012 & 0.0012 & 0.0003 & & 2.0 \\
\hline
\end{tabular}

In this calculation, cracked section bending rigidities of columns, beams shear walls are determined by analyzing bearing system under the vertical loads that is harmonic with masses according to TBEC-2018.

\subsection{Performance Evaluation with Nonlinear Dynamic Analysis}

It is assumed that nonlinear dynamic analysis defines structure behavior ideally because of the seismic loads directly applied to structure ( $\mathrm{Li}, 1996)$. The aim of nonlinear dynamic analysis is integration of equations of the motion of the system step by step by taking into consideration of nonlinear behavior of bearing system. It is calculated for each time increment that displacement, plastic deformation, internal forces occurred in the system and maximum values of them during earthquake.

The Newmark's method is used for solving the dynamic equilibrium equations. Although not as simple as the central difference method, it is perhaps the most popular method because of its superior accuracy.

The selection and scaling of the acceleration records to be used within the scope of this study were made within the framework of the principles given in TBEC-2018. At least 11 earthquake records should be used for nonlinear time history analyses. Response spectrums for scaled acceleration recordings are given in $\mathbf{F i g} . \mathbf{5}$ and scale coefficients in Table $\mathbf{5}$.

Table 5. Earthquake records applied in the building

\begin{tabular}{|l|l|l|l|l|l|l|l|}
\hline Earthquake & RSN & Earthquake & Year & Magnitude & Mechanism & $\mathrm{R}_{\text {rup }}(\mathrm{km})$ & Scale factor \\
\hline
\end{tabular}




\begin{tabular}{|c|c|c|c|c|c|c|c|}
\hline No & & & & & & & \\
\hline 1 & 164 & Parkfield & 1966 & 6.19 & \multirow{11}{*}{ Strike-Slip } & 15.96 & 2.61 \\
\hline 2 & 881 & Livermore-02 & 1980 & 5.42 & & 18.28 & 3.1 \\
\hline 3 & 1164 & Mammoth Lakes-03 & 1980 & 5.91 & & 18.13 & 2.96 \\
\hline 4 & 1166 & Mammoth Lakes-04 & 1980 & 5.7 & & 14.38 & 3.31 \\
\hline 5 & 1183 & Chalfant Valley-02 & 1986 & 6.19 & & 21.92 & 3.19 \\
\hline 6 & 1619 & Duzce, Turkey & 1999 & 7.14 & & 12.55 & 1.26 \\
\hline 7 & 1633 & Hector Mine & 1999 & 7.13 & & 11.66 & 1.76 \\
\hline 8 & 2107 & Landers & 1992 & 7.28 & & 25.02 & 2.12 \\
\hline 9 & 2113 & Big Bear & 1992 & 6.46 & & 29.06 & 3.09 \\
\hline 10 & 3757 & Joshua Tree, CA & 1992 & 6.1 & & 29.4 & 3.74 \\
\hline 11 & 8597 & Joshua Tree, CA & 1992 & 6.1 & & 21.97 & 4 \\
\hline
\end{tabular}

Nonlinear time history. analysis results such as lateral displacements and story drift ratios and shear forces are given to represent earthquake performance for the irregular tall buildings. The maximum displacements that occur at each floor level are given in Figs. 6-7, as are the story drift ratios in the Figs. 8-9. The lateral displacement values given in Figs. 6-7 receive the maximum value at the top of the building in $\mathrm{X}$ and $\mathrm{Y}$ directions. The relative story values obtained as a result of the calculations are compared with the limit values given in TBEC-2018. The average of the relative story displacement values obtained from the 11 acceleration records selected by TBEC2018 in Fig. 7 is compared with these limit values.

The story drift ratio of this point is one of the maximum values and much bigger than the allowed value of 0.08 . 

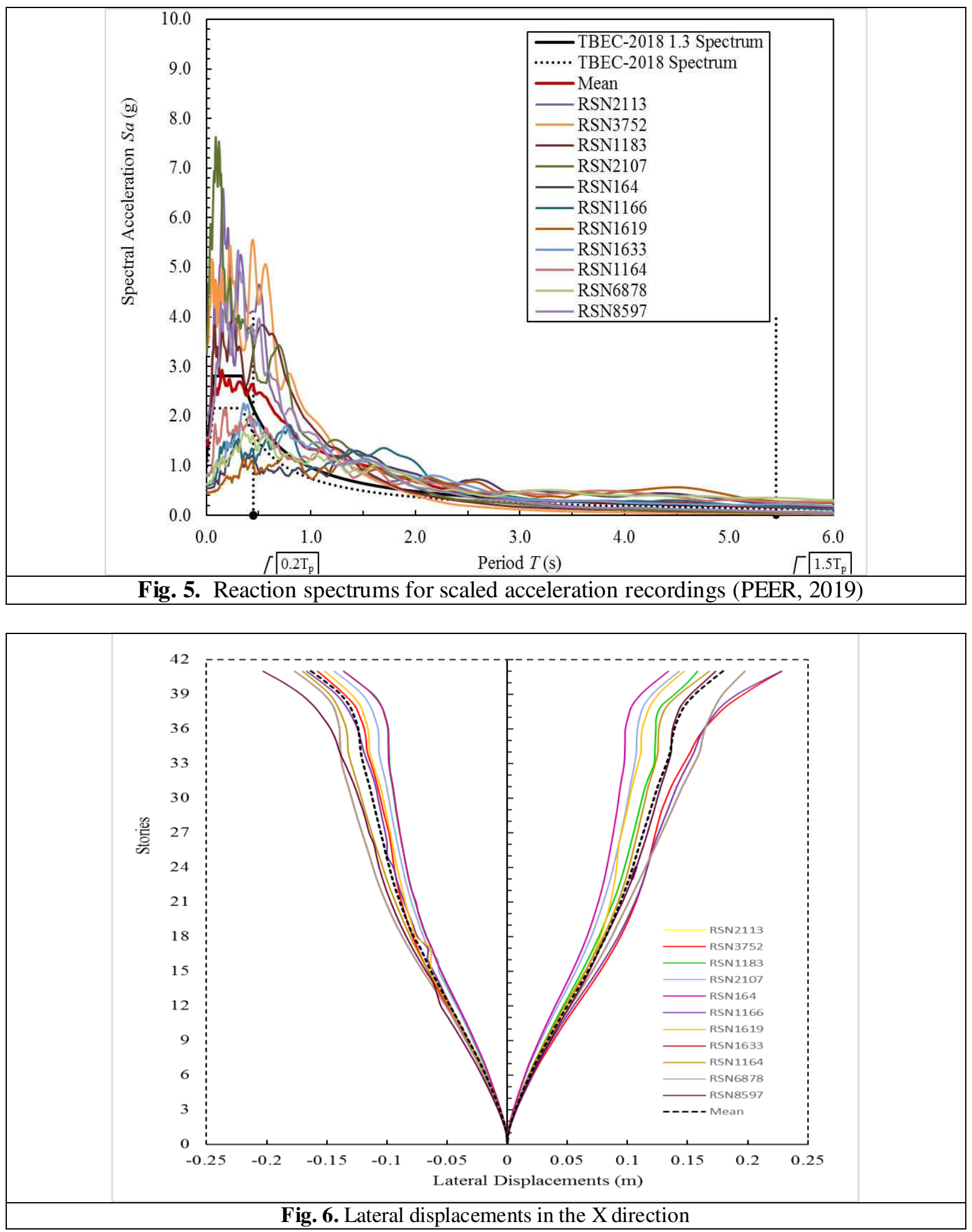

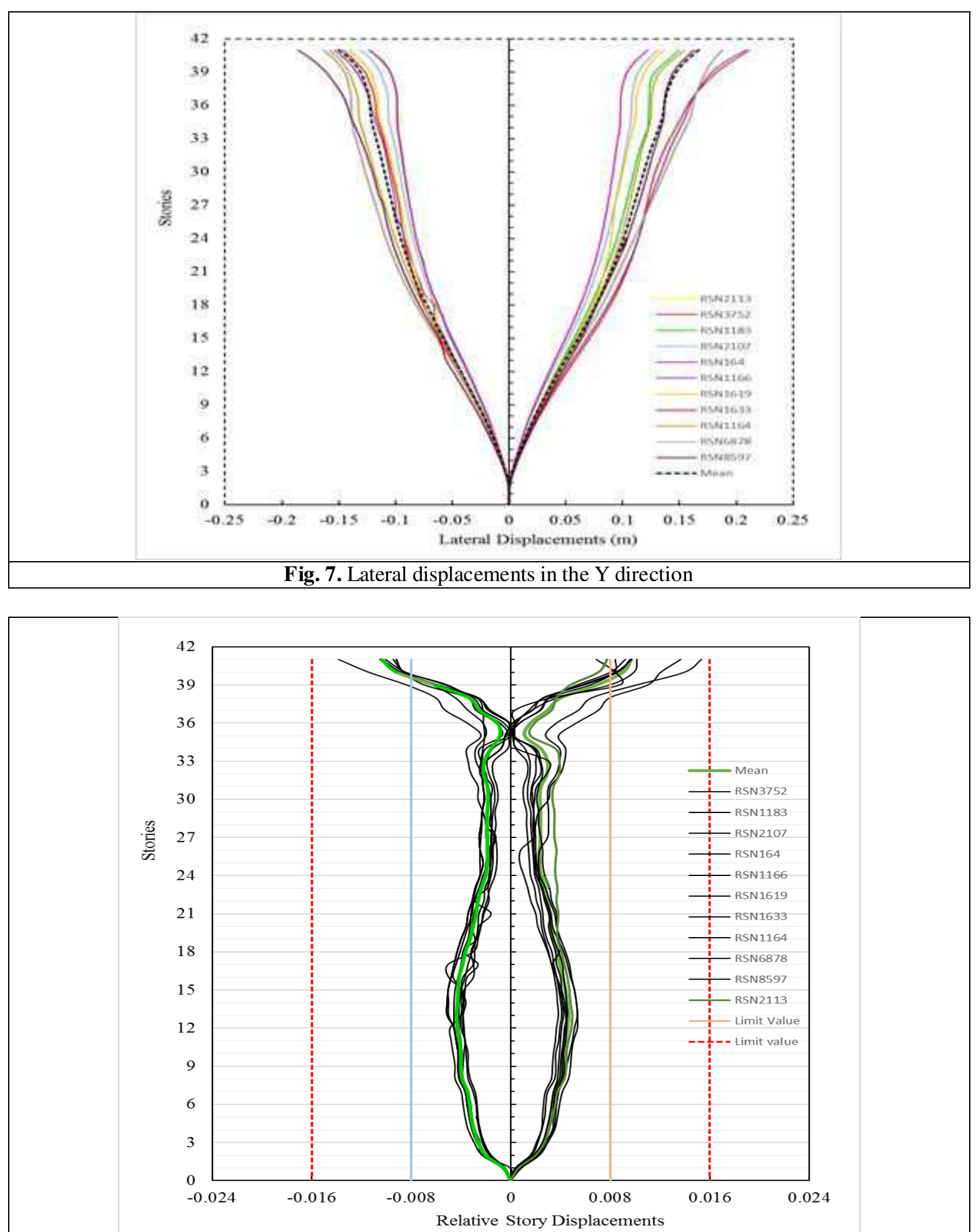

Fig. 8. Maximum relative story downward (-) and upward (+) displacements 

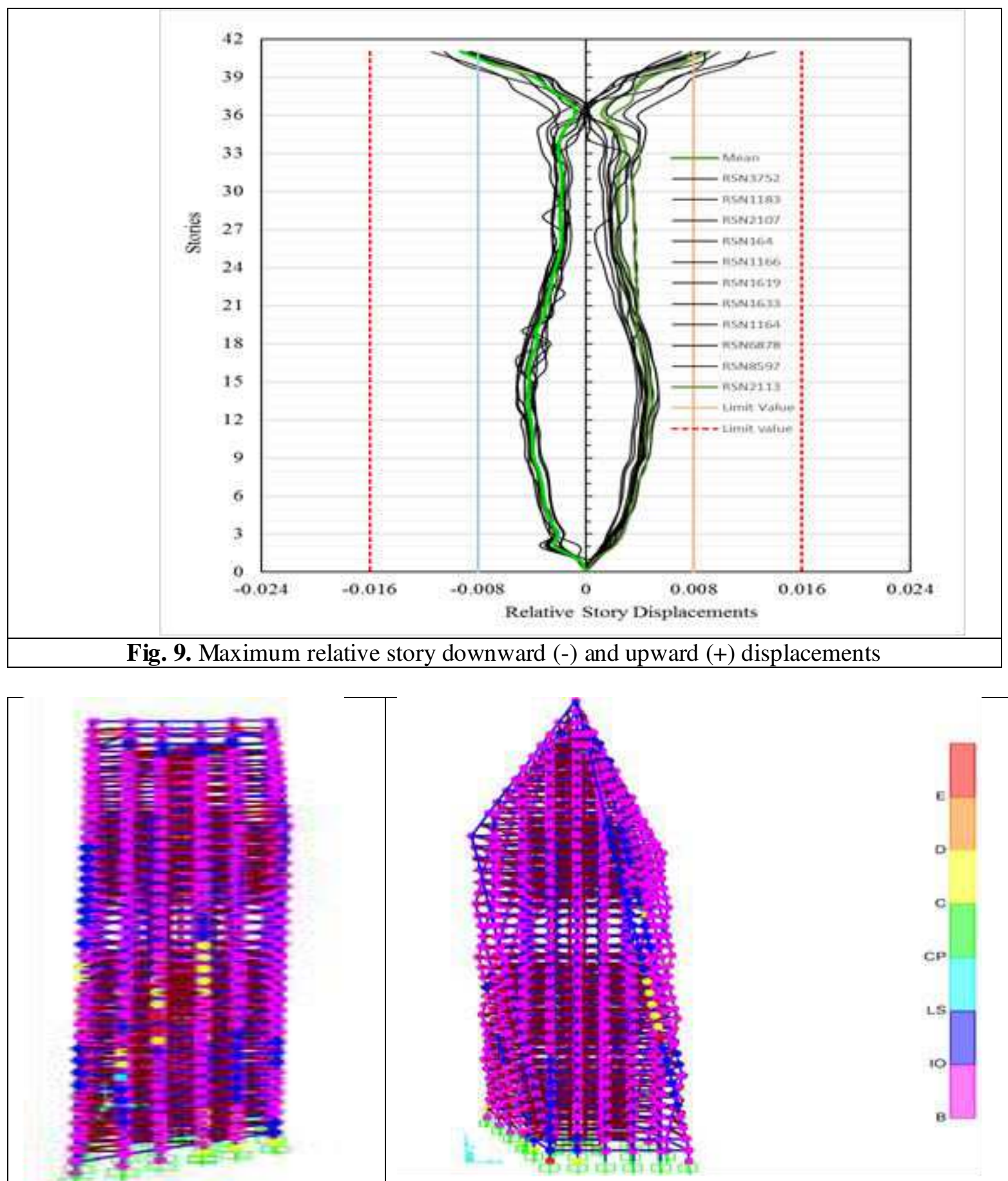

(a) X direction

(b) Y direction

Fig.10. The plastic hinges occurred through the $\mathrm{X}$ and $\mathrm{Y}$ directions of the building after nonlinear dynamic analysis. 
It is seen from Fig.10 that plastic hinges occurred through $\mathrm{X}$ and $\mathrm{Y}$ directions as a result of nonlinear dynamic analysis for the RSN-1619. It can be seen from Fig. 10 that these hinges are concentrated on at the ends of the oblique columns. It can be seen from the result of the nonlinear dynamic analysis through the $X$ and $Y$ directions (Fig. 10) that damage is occurred in the columns and beams. It can be also seen from the result of the nonlinear dynamic analysis 23 columns (23\%) of total columns are collapsed. It is seen from Fig.10 that collapse damages are occurred especially oblique columns of floors.

When the analysis results are investigated, it is concluded from nonlinear dynamic analysis that according to damage conditions of elements, the building does not provide life safety (LS) rating in TBEC-2018. The existing building is far from satisfying the expected performance levels. The performance level of the building is determined as advanced damage region $(\mathrm{GV})$.

In addition, the results of the Duzce earthquake that took place in the area where the building is located are given in Fig. 11. When the articulating elements were examined, it was seen that the hinges took place at the oblique column ends in the lower floors. In this case, the building may be migrated in the form of a floor mechanism in a possible earthquake. 


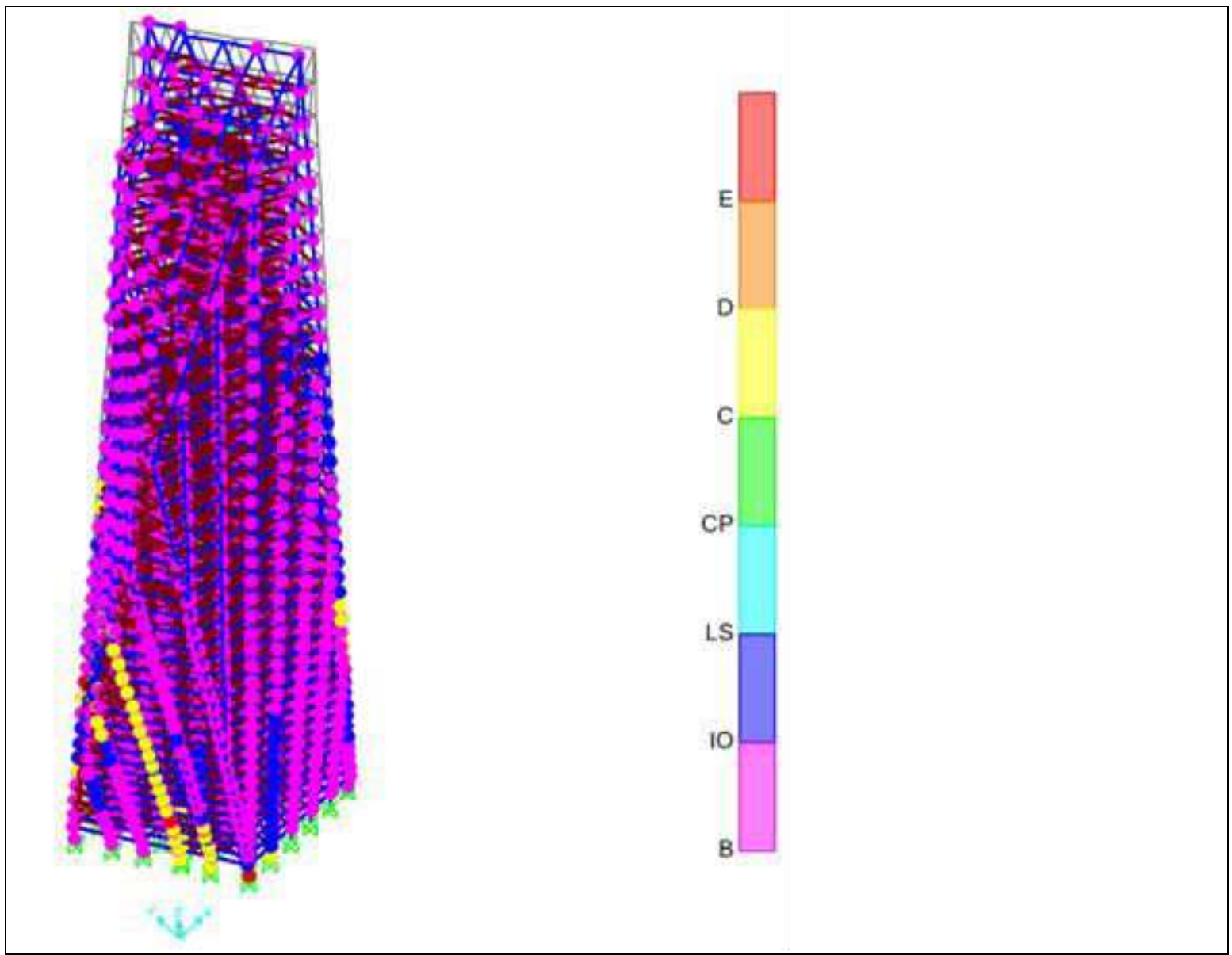

Fig. 11. The plastic hinges occurred for Duzce earthquake of the building after nonlinear dynamic analysis.

\section{Conclusion}

The purpose of performance-based earthquake engineering is to design and construct safe structures with seismic demands. The performance-based design method in earthquake engineering is used to determine the expected performance level under the effect of earthquake. For this purpose, different calculation methods have been developed and it is accepted by the scientific circles that the most reliable calculation methods are nonlinear calculation methods.

In this study, an existing building in Istanbul province is considered. One of the most important reasons for the selection of the existing structure in Istanbul is that the dangerous fault lines are present within the boundaries of this province and this city is under danger of approaching and inevitable Great Istanbul Earthquake likely greater than Mw 7. Thus, investigation of earthquake performances of this or similar tall buildings is very important. In line with this information, linear and nonlinear analysis of an existing structure according to TBEC-2018 was carried out. Mode Superposition Method was used in linear analysis and Non-linear Time History method was used nonlinear analysis method. 


\section{References}

Ahmad, N., (2021), "Force-based seismic design of steel haunch retrofit for RC frames", Earthquakes and Structures, https://doi: 10.12989/eas.2021.20.2.000

Armini, M.A. and Poursha, M., (2016), "A non-adaptive displacement-based pushover procedure for the nonlinear static analysis of tall building frames", Engineering Structures,126, 586-597, https://doi: 10.1016/j.engstruct.2016.08.009

Applied Technology Council, ATC-40 (1996), Seismic evaluation and retrofit of concrete buildings, California.

Duan, H., and Hueste, M.B., (2013), "Seismic performance of a reinforced concrete frame building in China", Engineering Structures, 41, 77-89. https:// doi:10.1016/j.engstruct.2013.11.029

EN 10080, (2005), Steel for the reinforcement of concrete - Weldable reinforcing steel - General, European Committee for Standardization.

EN 206-1, (2000), Concrete - Part 1: Specification, performance, production and conformity, European Committee for Standardization. 
FEMA-356 (2000), Federal Emergency Management Agency, Prestandard and

FEMA-440 (2005), Federal Emergency Management Agency, Improvement of nonlinear static seismic analysis procedures. Washington (DC).

Fredrick, A., Dyaa, C., Winston, A. and Oretaaa, C., (2017), "Seismic vulnerability assessment of soft story irregular buildings using pushover analysis", Procedia Engineering, 125, 925 - 932, doi: 10.1016/j.proeng.2015.11.103.

Guan, M.S., Liu, W.T.,Du, H.B., Cui, J. And Wang, J., (2019), "Combination model for conventional pushover analysis considering higher mode vibration effects", Structural Design of Tall and Special Buildings, 28, 12. https://doi.org/10.1002/tal.1260.

Mander, J.B., Pristley, M.J.N., Park, R. (1988), "Theoretical stress-strain model for confined concrete", Journal of Structural Division (ASCE), 114(8), 1804-1826. https://doi.org/10.1061/(ASCE)0733-9445(1988)114:8(1804).

Pavel, F., and Vacareanu, R., (2016), "Investigation on site conditions for seismic stations in Romania using H/V spectral ratio", Earthquakes and Structures, 9(5), 983-997. https:// doi: 10.12989/ eas.2015.9.5.983.

PEER (2020), (Pacific Earthquake Engineering Research Centre), http://peer.berkeley.edu/smcat/data.

Poursh, M., Khoshnoudian, F., and Moghadam, A.S., (2014), “The extended consecutive modal pushover procedure for estimating the seismic demands of two-way unsymmetric-plan tall buildings under influence of two horizontal components of ground motions", Soil Dynamics and Earthquake Engineering, 63, 162-173. https:// doi: 10.1016/j.soildyn.2014.02.001.

Sadjadi, R, Kianoush, M.R., Talebi, S. (2007), "Seismic performance of reinforced concrete moment resisting frames", Engineering Structures, 29(9), 2365-80. https:// doi:10.1016/j.engstruct.2006.11.029

SAP 2000, Structural Analysis Program, Computers and Structures Inc., Berkeley, California.

Tehranizadeh, M., and Moshref, A., (2011) "Performance-based optimization of steel moment resisting frames", Scientia Iranica A, 18 (2), 198-204. https://doi.org/10.1016/j.scient.2011.03.029 
429 Turkish Earthquake Code (TEC-1975) (1975). Specifications for buildings to be built in 430 seismic areas. Ministry of Public Works and Settlement. Ankara, Turkey. [in Turkish]

431

432

433

434

435

436

437

438

439

440

441

442

443

444

445

446

447

448

449

450

451 Ethics declarations

452 Conflicts of interest

453 The authors declare that they have no conflict of interest. Settlement, Ankara, Turkey. of Public Works and Settlement. Ankara, Turkey. $\underline{10.12989 / \text { eas.2016.10.2.293 }}$ https://doi.org/10.1177/1369433220933463. Associates Inc., Sacremanto, California.

454

455

TBEC-2018 (2018), Turkey Building Earthquake Code, Ministry of Public Works and

DBYBHY-2007 (2007), Specifications for buildings to be built in seismic areas. Ministry

Vasiliadis, L., (2016). Seismic evaluation and retrofitting of reinforced concrete buildings with base isolation systems, Earthquakes and Structures 10(2), 293-311, https://doi:

Ye, L., Qu, Z., Ma, Q., Lin, X., Lu, X., Pan, P., (2008)'Study on ensuring the strong column weak beam mechanism for RC frames based on the damage analysis in the Wenchuan earthquake", Build Structures; $38(11), \quad$ 52-9.

XTRACT, 2004. Cross Sectional Analysis of Structural Components, Imbsen and 